\title{
ARTYKUŁY
}

Agata Lizak

agata_lizak@interia.pl

orcid.org/0000-0002-0450-1828

Szkoła Doktorska Uniwersytetu Rzeszowskiego

al. Tadeusza Rejtana 16c

35-959 Rzeszów

\section{Problematyka właściwego}

wyeksponowania zabytków ruchomych

z perspektywy administracyjnoprawnej

The problem of adequate display of movable monuments from the perspective of administrative law

Summary: As regards the Act of $23^{\text {rd }}$ July 2003 on the Protection of Monuments and the Guardianship of Monuments, there are no regulations directly addressing the problem of display of movable monuments. Yet, similarly to immovable monuments' surroundings (which are legally protected under certain conditions), movable heritage surroundings may also exert an influence on objects' historic, artistic or scientific value. This article examines four main aspects of the aforementioned problem, including a discussion on how and in which cases the protection of immovable monuments may automatically ensure the protection of movable property's surroundings. Moreover, this analysis concerns the scope of the legal restriction of permanent relocation of movable monuments, violating traditional notions of interior design. Next, attention is given to the specific protection of monument surroundings mistakenly qualified as movable (e.g., small architectural elements). It further considers to what extent the obligation to ensure adequate display of movable monuments results from a general obligation imposed on the monument's owner or possessor. In addition to a black letter analysis of current legal provisions, the analysis comprises elements of the historic evolution of regulation in this context. Furthermore, an attempt to formulate postulates de lege ferenda has been made. 


\section{ARTYKUEY}

Agata Lizak

Keywords: movable monument, the act on the protection of monuments and the guardianship of monuments, historic monument's surrounding, historic monument's exposition

Streszczenie: W ustawie $z$ dnia 23 lipca 2003 r. o ochronie zabytków i opiece nad zabytkami brak jest przepisów, które wyczerpująco odnosiłyby się do problemu właściwego wyeksponowania zabytków ruchomych. Tymczasem, podobnie jak ma to miejsce w przypadku otoczenia zabytków nieruchomych (podlegającego w pewnych przypadkach ochronie), tak i otoczenie ruchomości może pośrednio wpływać na ich wartość historyczną, artystyczną czy naukową. W artykule poruszone zostały cztery główne aspekty problemu. Omówiono, na ile ochronę otoczenia zabytku ruchomego zapewnia ochrona zabytku nieruchomego, w którym ten pierwszy się znajduje. Przeanalizowano zakres prawnego ograniczenia możliwości trwałego przeniesienia zabytku ruchomego wpisanego do rejestru, z naruszeniem ustalonego tradycją wystroju wnętrza. Skupiono się na problematyce ochrony otoczenia zabytków w istocie błędnie zakwalifikowanych jako ruchome (np. elementów małej architektury). Rozważono także, na ile konieczność właściwego wyeksponowania zabytku wynika z ogólnych obowiązków jego dysponenta. W artykule, poza formalno-dogmatyczną analizą przepisów de lege lata, przedstawiono także elementy ewolucji przepisów na omawiany temat. Podjęto również próbę sformułowania postulatów de lege ferenda.

Słowa kluczowe: zabytek ruchomy, ustawa o ochronie zabytków i opiece nad zabytkami, otoczenie zabytku, wyeksponowanie zabytku

\section{Wprowadzenie}

Problematykę właściwego wyeksponowania zabytku na tle innych obiektów zwykło się analizować przede wszystkim w kontekście ochrony wartości widokowych zabytków nieruchomych. Również ustawodawca kwestię tę zdaje się wiązać przede wszystkim z zabytkami nieruchomymi, wyłącznie do nich odnosząc pojęcie otoczenia, rozumiane zgodnie z definicją z art. 3 pkt 15 ustawy z dnia 23 lipca 2003 r. o ochronie zabytków i opiece nad zabytkami ${ }^{1}$ (dalej: u.o.z.) jako „teren wokół lub przy zabytku wyznaczony w decyzji o wpisie tego terenu do rejestru

1 Ustawa z dnia 23 lipca 2003 r. o ochronie zabytków i opiece nad zabytkami, tekst jedn. Dz. U. z 2018 r., poz. 2067 ze zm. 
zabytków w celu ochrony wartości widokowych zabytku oraz jego ochrony przed szkodliwym oddziaływaniem czynników zewnętrznych"2.

W istocie, o ile zabytki nieruchome co do zasady stanowią element przestrzeni publicznej, kształtując krajobraz (także ten kulturowy) i wpływając na jego estetykę, o tyle w przypadku zabytków ruchomych, zwykle przechowywanych we wnętrzach budynków, prawna ingerencja w ich odpowiednie wyeksponowanie może na pierwszy rzut oka wydawać się mniej uzasadniona. Trzeba w tym miejscu pamiętać, że żaden z przepisów nie nakłada na właścicieli czy posiadaczy zabytków obowiązku ich publicznego udostępniania - w tym kontekście problem wyeksponowania (wiążącego się zasadniczo również z wystawieniem na pokaz ${ }^{3}$ ) zdaje się być, przynajmniej w niektórych przypadkach, bezprzedmiotowy. Niemniej jednak wiele obiektów ruchomych funkcjonuje w przestrzeni publicznej, mając utrwalone i uzasadnione historyczne, artystycznie lub funkcjonalnie umiejscowienie - tak jest chociażby w przypadku elementów wyposażenia zabytkowych świątyń, stanowiących największą grupę wśród zabytków ruchomych ${ }^{4}$. W tym kontekście postrzeganie zabytków ruchomych w oderwaniu od umiejscowienia może prowadzić do zaburzenia ich kontekstu historycznego, artystycznego czy naukowego, a tym samym niekiedy nawet do obniżenia wartości, które decydowały o wpisie danego obiektu do rejestru zabytków ruchomych.

Celem artykułu jest zatem próba odpowiedzi na pytanie, czy brak bezpośredniego odniesienia się $w$ ustawie o ochronie zabytków i opiece nad zabytkami do właściwego wyeksponowania zabytków ruchomych jest świadomym zabiegiem ustawodawcy, czy też w przepisach istnieje luka aksjologiczna. Za pierwszą z opcji zdaje się przemawiać wspomniany już fakt, że nie istnieje prawny obowiązek publicznego eksponowania zabytków ruchomych, a problem właściwej ekspozycji może zdawać się wobec tego wtórny. Niemniej jednak problematyka ta jest regulowana pośrednio (m.in. poprzez ograniczenia w zakresie przemieszczania tego typu obiektów) i w tym zakresie można zastanawiać się, na ile postanowienia ustawy o ochronie zabytków i opiece nad zabytkami są trafne. Jako pewien punkt odniesienia przyjęto regulacje nieobowiązującej już ustawy z dnia 15 lutego 1962 r. o ochro-

\footnotetext{
2 Choć w zacytowanej definicji mowa jest o zabytkach w ogólności (bez odniesienia do ich poszczególnych kategorii), przedwczesne byłoby oparcie się wyłącznie na wykładni lege non distinguente. Po pierwsze, dalsze przepisy ustawy o ochronie zabytków i opiece nad zabytkami możliwość wpisu otoczenia do rejestru zabytków przewidują wyłącznie w odniesieniu do otoczenia zabytków nieruchomych (zob. art. 9 ust. 2 u.o.z.). Po drugie, w przypadku zabytków ruchomych niezasadne wydaje się odwołanie do pojęć takich jak „teren” czy "wartości widokowe" - na ich otoczenie składa się bowiem raczej konkretny układ wnętrza, w którym są umiejscowione, zaś zamiast o wartościach widokowych trafniej byłoby mówić o właśnie o odpowiednim wyeksponowaniu.

3 B. Dunaj (red.), Słownik wspótczesnego języka polskiego, t. 1, Wydawnictwo Wilga, Warszawa 1998, s. 230.

4 Zgodnie z danymi Narodowego Instytutu Dziedzictwa, wyposażenie świątyń stanowi ok. 74\% wszystkich obiektów wpisanych do rejestru jako zabytki ruchome (zob. https://www.nid.pl/pl/Informacje_ogolne/ Zabytki_w_Polsce/rejestr-zabytkow/zestawienia-zabytkow-ruchomych/[dostęp: 3.04.2020]).
} 


\section{ARTYKUEY}

Agata Lizak

nie dóbr kultury ${ }^{5}$ (dalej: u.o.d.k.), rozważając, czy przewidziane w niej rozwiązania lepiej uwzględniały specyfikę ochrony zabytków ruchomych.

W artykule ograniczono się do formalno-dogmatycznej analizy przepisów, uzupełnionej refleksją historyczno-prawną. Kwestia badań empirycznych, dotyczących tego, jak zabytki ruchome są w rzeczywistości eksponowane i jak w praktyce przebiega nadzór konserwatorski w tym zakresie, może być natomiast przedmiotem dalszych prac. Ponadto $w$ tekście skupiono się na zabytkach ruchomych wpisanych do rejestru' ${ }^{6}$ Trzeba przy tym wskazać, że ze względu na fakt, iż regulacje ustawy o ochronie zabytków i opiece nad zabytkami nie różnicują zakresu ochrony zabytków ruchomych od okoliczności, czy dany przedmiot jest udostępniany publiczności, rozważania prezentowane $w$ artykule mogą odnosić się także do zbiorów prywatnych. Samo pojęcie wyeksponowania dla celów niniejszego tekstu należy natomiast rozumieć w szerokim znaczeniu, jako podkreślające walory zabytku ruchomego umieszczenie go na tle innych obiektów.

\section{Właściwe wyeksponowanie zabytków ruchomych jako konsekwencja ochrony zabytków nieruchomych}

Mając na uwadze, że sytuacja, w której za zabytek ruchomy uznane zostaje wyposażenie zabytku nieruchomego, jest najbardziej typowa, warto w pierwszej kolejności zastanowić się, czy ochrony otoczenia zabytków ruchomych pod kątem ich właściwego wyeksponowania nie zapewnia automatycznie ochrona budynku, w którym się znajdują.

Wprowadzony w ustawie o ochronie zabytków i opiece nad zabytkami podział na zabytki ruchome oraz nieruchome zakłada dualizm w podejściu do ich ochrony, przewidując niejednokrotnie odmienne środki nadzoru konserwatorskiego i odmienne obowiązki ze strony posiadaczy lub właścicieli zabytków. Niemniej wiele postanowień odnoszących się do zabytków nieruchomych ma przełożenie na ich wyposażenie. Przykładowo, pozostające przedmiotem nadzoru konserwatorskiego prace konserwatorskie i restauratorskie prowadzone względem zabytku nieruchomego wpisanego indywidualnie do rejestru (zob. art. 36 ust. 1 pkt 1 u.o.z.) mogą dotyczyć także jego poszczególnych pomieszczeń wewnętrznych, stanowiących bezpośrednie otoczenie znajdujących się w nich ruchomości.

Nie oznacza to jednak, że obecny stan prawny nie budzi wątpliwości. Wskazać w tym miejscu należy, że ochrona wnętrz w przypadku zabytków nieruchomych jest ograniczona, odnosi się bowiem zasadniczo tylko do części składowych danego obiektu (np. ścian, podłóg, drzwi), a nie poszczególnych elementów wyposażenia,

5 Ustawa z dnia 15 lutego 1962 r. o ochronie dóbr kultury, tekst jedn. Dz. U. z 1999 r. Nr 98, poz. 1150 ze zm.

6 Ze względu na ograniczenia objętościowe formy artykułu pominięte zostały m.in. muzealia, omówienie sytuacji których wymagałoby również sięgnięcia do przepisów ustawy z dnia 21 listopada 1996 r. o muzeach (tekst jedn. Dz.U. z 2019 r., poz. 917 ze zm.). 
podlegających ewentualnie odrębnej ochronie indywidualnej. W konsekwencji, zgodnie z literalną wykładnią przepisów, dopuszczalne jest przykładowo, by zabytek ruchomy był otoczony, czy wręcz przesłoniony, przez rzeczy zniszczone bądź całkowicie doń niepasujące pod względem estetycznym. Choć sytuacja taka nie zawsze będzie negatywnie wpływać na jego wyeksponowanie - co więcej, niekiedy może być uzasadniona, np. w przypadku umiejscowienia w jednym pomieszczeniu obiektów z różnych okresów, reprezentujących różne style, $w$ celu pokazania ich ewolucji - to brak formalnej możliwości nadzoru w tym zakresie może być uznany za pewną lukę, zwłaszcza w odniesieniu do zbiorów publicznych.

Problem ten w pewnym stopniu rozwiązany był na gruncie poprzednio obowiązującej ustawy o ochronie dóbr kultury, w której art. 5 wśród rzeczy podlegających ochronie expressis verbis jako jedną kategorię wymieniono „budowle i ich wnętrza wraz z otoczeniem". Co istotne, jako że w ustawie o ochronie dóbr kultury nie rozróżniano tak silnie jak obecnie ochrony zabytków nieruchomych i ruchomych, można uznać, że przez pojęcie wnętrza rozumiano także jego ruchome elementy’ Również w piśmiennictwie podkreśla się, że w okresie obowiązywania ustawy o ochronie dóbr kultury wyposażenie stanowiące spójną całość z zabytkiem nieruchomym i wykazujące $z$ nim związki historyczne lub tradycyjne samoistnie podlegało ochronie, i to nawet jeśli samo nie wykazywało cech zabytku8.

Analizując dalej przepisy ustawy o ochronie dóbr kultury, warto zwrócić uwagę na treść art. 27 ust. 1 u.o.d.k., zgodnie z którym bez zezwolenia wojewódzkiego konserwatora zabytków nie wolno było zabytków przerabiać, odnawiać, rekonstruować, konserwować, zabudowywać, odbudowywać, zdobić, uzupełniać, rozkopywać ani dokonywać żadnych innych zmian. Nawet jeśli uznać brzmienie powołanego przepisu za zbyt szerokie (zgodnie z jego ścisłą wykładnią, niemal każda, nawet najdrobniejsza zmiana wymagałaby działania nadzorczego ze strony właściwego organu'),

\footnotetext{
7 Warto podkreślić, że takie rozumienie zabytków zasadniczo nie było przedmiotem kontrowersji w ówczesnej doktrynie. Choć wielokrotnie podejmowano się ocen funkcjonowania ustawy o ochronie dóbr kultury, nie unikając formułowania propozycji co do jej nowelizacji, wyliczenie przedmiotów podlegających ochronie z art. 5 u.o.d.k. uznawano za prawidłowe (zob. np. J. Pruszyński, Regulacja ustawowa ochrony zabytków, „Ochrona Zabytków” 1985, nr 38/1(148), s. 29; W. Sieroszewski, Czy ustawa o ochronie dóbr kultury i o muzeach dojrzała do nowelizacji: artykuł dyskusyjny, „Ochrona Zabytków” 1971, nr 24/3(94), s. 163-172). Podobne propozycje definiowania zabytków przedstawiano także w odniesieniu do projektów nowej ustawy - przykładowo J. Pruszyński sugerował, by ochroną objąć „obiekty architektury i budownictwa miejskiego i wiejskiego wraz z wystrojem, otoczeniem lub strefą ochrony konserwatorskiej" (zob. J. Pruszyński, Stan i potrzeby regulacji prawnej ochrony zabytków w Polsce, „Ochrona Zabytków” 1996, nr 49/3(194), s. 296).

8 Pogląd ten znajdował odzwierciedlenie w praktyce - niejednokrotnie do rejestru wpisywano łącznie zabytek nieruchomy z wyposażeniem, co w praktyce pozwalało na traktowanie zabytku nieruchomego i znajdujących się w nim zabytków ruchomych jako jednego przedmiotu ochrony. Obecnie powielanie takiego rozwiązania jest niemożliwe, chociażby z tego względu, że zgodnie z art. 8 ust. 2 u.o.z., rejestr prowadzony jest odrębnie dla zabytków nieruchomych i ruchomych (zob. A. Jagielska-Burduk, Zabytek ruchomy, Wolters Kluwer Polska, Warszawa 2011, s. 206).

9 Na problem nietrafnego sformułowania obowiązków dysponentów zabytków w ustawie o ochronie dóbr kultury zwracał uwagę m.in. J. Pruszyński, twierdząc, że "są one w ustawie określone zbyt szeroko
} 


\section{ARTYKUEY}

Agata Lizak

to przyznać trzeba, że w sposób pełniejszy odnosiło się do zabytku nieruchomego z całym jego wyposażeniem. Przykładowo, w świetle wspomnianej regulacji nadzorem objęte byłyby takie czynności jak uzupełnianie wyposażenia budynku o nowe rzeczy, które mogłyby przesłonić lub nawet zastąpić w funkcjach dotychczasowe zabytki ruchome.

Wskazać również należy, że traktowanie zabytku nieruchomego integralnie $z$ jego ruchomym wyposażeniem wydaje się być preferowane na gruncie prawa międzynarodowego. Dowodzi tego art. 1 ratyfikowanej przez Polskę konwencji o ochronie dziedzictwa architektonicznego Europy z dnia 3 października 1985 r. (dalej: konwencja) ${ }^{10}$, zgodnie z którą za zabytki uznaje się wszelkie budowle i obiekty wyróżniające się szczególną wartością historyczną, archeologiczną, artystyczną, naukową, społeczną lub techniczną, włącznie z ich częściami składowymi i wyposażeniem ${ }^{11}$. Choć we wspomnianym przepisie wyraźnie zaznaczono, że definicja ta sformułowana została dla celów konkretnego aktu prawnego, wskazuje ona kierunek, jaki warto uwzględnić przy stanowieniu prawa wewnętrznego. Jest to istotne o tyle, że przy węższym rozumieniu zabytku w ustawie o ochronie zabytków i opiece nad zabytkami trudno może być o pełną realizację postanowień konwencji $^{12}$ - przykładowo, szerszą niż przewidziana w ustawie o ochronie zabytków i opiece nad zabytkami ochronę przewiduje związany pośrednio z kwestią wyeksponowania art. 5 konwencji, zgodnie z którym strony powinny wprowadzić zakaz usuwania całości lub części każdego obiektu zabytkowego, chyba że jest to uzasadnione stanem technicznym. Interpretując ten przepis w zgodzie z definicją zabytku $z$ art. 1 konwencji, zabronione powinno być także usuwanie elementów wyposażenia danej budowli, co zasadniczo nie jest wprost przewidziane $w$ aktualnie obowiązujących przepisach krajowych. Podobnie zastanawiać się można, czy Polska spełnia ogólne zobowiązanie do wprowadzenia systemu ochrony prawnej dziedzictwa architektonicznego (art. 3 konwencji), skoro niecałe dziedzictwo architektoniczne jest przedmiotem ustawy o ochronie zabytków i opiece nad zabytkami.

Rozważania te pokazują, że w ustawie o ochronie zabytków i opiece nad zabytkami zabrakło przepisów pozwalających na objęcie jednolitą ochroną budowli i jej wnętrza. Tym samym nie ma podstaw do integralnego, całościowego spojrzenia

a jednocześnie zbyt ogólnikowo, powodując przeświadczenie, że nie można ich przestrzegać, co prowadzi do faktycznego ich nieprzestrzegania" (zob. J. Pruszyński, Regulacja..., s. 30).

10 Konwencja o ochronie dziedzictwa architektonicznego Europy z dnia 3 października 1985 r., Dz. U. z 2012 r., poz. 210.

11 W wyjaśnieniach do konwencji zaznacza się, że przez pojęcie wyposażenia należy rozumieć np. dzieła sztuki czy maszyny (zob. Explanatory report on the Convention for the Protection of the Architectural Heritage of Europe, https://rm.coe.int/CoERMPublicCommonSearchServices/DisplayDCTMContent?documen$\mathrm{tld}=09000016800 \mathrm{ca} 436$ [dostęp: 2.04 .2020$]$ ).

12 Istnienie luk w ustawie o ochronie zabytków i opiece nad zabytkami względem zobowiązań wynikających z konwencji dostrzeżono w doktrynie (zob. np. K. Zeidler, Nowe zobowiazania międzynarodowe Polski w zakresie ochrony dziedzictwa kultury, „Gdańskie Studia Prawnicze” 2013, t. 29, s. 341). 
na dany zabytek, na którego walory estetyczne wpływać może również umiejscowienie w nim lub wokół niego innych obiektów ${ }^{13}$. Przepisy ustawy o ochronie dóbr kultury, a także postanowienia konwencji mogą zatem służyć jako podstawa dla rozważań de lege ferenda. Warto jednak zastanowić się, czy intensywności środków ochrony nie uzależnić od okoliczności, czy wnętrza budynków są publicznie eksponowane (w ustawie o ochronie dóbr kultury brak było takiego rozróżnienia, przez co ingerencja mogła literalnie dotyczyć zbiorów prywatnych).

\section{Właściwe wyeksponowanie zabytków ruchomych a ochrona ustalonego tradycją wystroju wnętrza}

Przy rozważaniach o ochronie otoczenia zabytku ruchomego nie sposób pominąć przepisów ustawy o ochronie zabytków i opiece nad zabytkami nakierowanych na ograniczenie możliwości trwałego przeniesienia zabytku ruchomego wpisanego do rejestru, z naruszeniem ustalonego tradycją wystroju wnętrza, w którym zabytek ten się znajduje. Jak wynika z ustawy o ochronie zabytków i opiece nad zabytkami, takie przeniesienie możliwe jest w stosunku do zabytków ruchomych wpisanych do rejestru jedynie w przypadku uzyskania pozwolenia wojewódzkiego konserwatora zabytków (art. 36 ust. 1 pkt 7 u.o.z.). W przypadku dokonania przeniesienia bez wymaganego pozwolenia lub w sposób odbiegający od zakresu i warunków określonych w pozwoleniu wskazany organ zobligowany jest do wydania decyzji o wstrzymaniu prac (art. 43 ust. 1 pkt 4 u.o.z.), a także decyzji nakazującej przywrócenie zabytku do poprzedniego stanu, określając termin wykonania tej czynności albo zobowiązującą do doprowadzenia zabytku do jak najlepszego stanu we wskazany sposób i w określonym terminie (art. 45 ust. 1 pkt 5 u.o.z.).

Warto zastanowić się szerzej nad zakresem wprowadzonego przez ustawodawcę ograniczenia. Jest ono niezależne od statusu miejsca, w którym znajduje się zabytek, toteż znajduje zastosowanie wobec wnętrz umiejscowionych tak w zabytkach nieruchomych, jak i innych obiektach. Literalnie ograniczenie ingerować może

\footnotetext{
13 Warto również podkreślić, że integralność nieruchomości oraz jej wyposażenia w sposób podobny do tego, jak uczyniono to w ustawie o ochronie dóbr kultury, regulowana jest niekiedy obecnie w prawodawstwie innych państw, co dowodzi aktualności takiego podejścia. Jako przykład wskazać można na norweską ustawę z dnia 9 czerwca 1978 r. o ochronie dziedzictwa kulturowego (Act of 9 June 1978, No. 50, Concerning the Cultural Heritage, https://www.regjeringen.no/en/dokumenter/cultural-heritage-act/id173106/ [dostęp: 3.04.2020]), której § 15 przewiduje możliwość objęcia ochroną nieruchomości wraz z ich stałym wyposażeniem (np. piecami). Ujęcie wydaje się nieco węższe aniżeli w ustawie o ochronie dóbr kultury (gdzie ochroną ex lege objęto wnętrza budowli, bez rozróżnienia na wyposażenie stałe i inne), niemniej w dalszej części przepisu wskazano, że ochrona dotyczyć może w uzasadnionych przypadkach także pozostałych przedmiotów ruchomych znajdujących się w danym obiekcie. Co więcej, podobnie jak w art. 27 ust. 1 u.o.d.k., szeroko określono zakres ochrony: według obowiązujących w Norwegii przepisów, wyposażenia nieruchomości nie można przenosić, demontować, modyfikować, uzupełniać, zmieniać kolorystyki czy materiałów, z których zostały wykonane, czy też dokonywać wszelkich innych zmian, poza tymi wynikającymi z codziennego użytkowania przedmiotów.
} 


\section{ARTYKUEY}

Agata Lizak

we wnętrza całkowicie prywatne. W takich przypadkach, ze względu na konflikt interesu publicznego i osobistego, ograniczenia co do przenoszenia zabytku ruchomego powinny być stosowane ostrożnie i proporcjonalnie do celu, jakim jest w zachowanie zabytku wraz z jego tradycyjnym kontekstem.

Co więcej, zgodnie $z$ art. 36 ust. 1 pkt 7 u.o.z., ograniczenie w przenoszeniu zabytków ruchomych dotyczy wyłącznie przeniesienia trwałego. Jest to zrozumiałe chociażby z tego względu, że zabytki ruchome niejednokrotnie muszą być przemieszczane czasowo celem wykonania na nich prac konserwatorskich czy restauratorskich; pod określonymi warunkami możliwe jest także ich wypożyczanie w celach wystawienniczych. Wskazać przy tym należy, że sformułowanie „trwały” jest pojęciem niedookreślonym. Choć intuicyjnie może kojarzyć się z definitywnym przeniesieniem zabytku, trzeba pamiętać, że językowe znaczenie pojęcia „trwały” jest równoznaczne z wyrażeniem: „istniejący przez dłuższy czas lub nieulegający szybkim zmianom"14. To zaś oznacza, że stosownego pozwolenia wymagać może również ze swej istoty tymczasowe, lecz długotrwałe przeniesienie zabytku. Potwierdzeniem tej tezy może być fakt, że - zgodnie z $§ 15$ ust. 1 pkt 5 rozporządzenia Ministra Kultury i Dziedzictwa Narodowego z dnia 22 czerwca 2017 r. w sprawie prowadzenia prac konserwatorskich, prac restauratorskich i badań konserwatorskich przy zabytku wpisanym do rejestru zabytków albo na Listę Skarbów Dziedzictwa oraz robót budowlanych, badań architektonicznych i innych działań przy zabytku wpisanym do rejestru zabytków, a także badań archeologicznych i poszukiwań zabytków ${ }^{15}$ - pozwolenie na przeniesienie zabytku ruchomego powinno określać termin swojej ważności, a contrario zatem - nie jest pozwoleniem bezterminowym. Z punktu widzenia właściciela zabytku ruchomego może w tym zakresie powstać niepewność co do określenia cezury czasowej obligującej do ubiegania się o pozwolenie, zwłaszcza że istnieją sytuacje, których czas trwania nie zawsze da się z góry określić.

Skupić warto się także na przesłance, jaką jest spowodowanie przez przeniesienie zabytku ruchomego naruszenia ustalonego tradycją wystroju wnętrza, w którym zabytek ten się znajduje. Mając na względzie redakcję art. 36 ust. 1 pkt 7 u.o.z., może nawet wydawać się, że głównym celem ustawodawcy jest nie tyle ochrona otoczenia zabytku ruchomego, ile ochrona samego wnętrza, którego zabytek ten jest tradycyjnym elementem. Biorąc pod uwagę, że, jak już wspomniano, wnętrze samo w sobie nie musi być zabytkowe (czy też być elementem zabytku nieruchomego), pozostaje to w pewnej niekonsekwencji z przedmiotem regulacji

14 B. Dunaj (red.), Słownik współczesnego języka polskiego, t. 2, Wydawnictwo Wilga, Warszawa 1998, s. 444.

15 Rozporządzenie Ministra Kultury i Dziedzictwa Narodowego z dnia 22 czerwca 2017 r. w sprawie prowadzenia prac konserwatorskich, prac restauratorskich i badań konserwatorskich przy zabytku wpisanym do rejestru zabytków albo na Listę Skarbów Dziedzictwa oraz robót budowlanych, badań architektonicznych i innych działań przy zabytku wpisanym do rejestru zabytków, a także badań archeologicznych i poszukiwań zabytków, Dz. U. poz. 1265. 
ustawy o ochronie zabytków i opiece nad zabytkami. Niemniej zauważyć należy, że przesłanką obligującą do uzyskania pozwolenia nie jest naruszenie otoczenia zabytku ruchomego, lecz naruszenie wystroju wnętrza w wyniku usunięcia z niego zabytku ruchomego. Wskutek tego organ jedynie w ograniczony sposób może ingerować w wybór miejsca, do którego zabytek ruchomy miałby zostać przeniesiony - punktem odniesienia jest przede wszystkim wnętrze dotychczasowe.

Co prawda zarówno we wniosku o wydanie pozwolenia na przeniesienie zabytku ruchomego, jak i w pozwoleniu na dokonanie tej czynności, miejsce, do którego zabytek ma być przeniesiony, powinno być obligatoryjnie wskazane brak jest bowiem normatywnych podstaw, by miało to samo w sobie przesądzać o rozstrzygnięciu zawartym w pozwoleniu (chyba że nie pozwala ono na wypełnianie przez właściciela obowiązków w zakresie opieki nad zabytkami określonych w art. 5 u.o.z.). Dalej, hipoteza tak rozumianego art. 36 ust. 1 pkt 7 u.o.z. nie powinna odnosić się do sytuacji, w których zabytek jest przenoszony co prawda na dłuższy czas, ale ma to związek wyłącznie z remontem wnętrza, w którym się znajduje (w rezultacie w żaden sposób nie są regulowane warunki tymczasowej ekspozycji zabytku w innym miejscu). Zabytek ruchomy może być właściwie swobodnie przemieszczany, jeśli wobec innych elementów wystroju stanowi dodatek późniejszy, jest dla danego wnętrza mało charakterystyczny lub jest powtarzalny ${ }^{16}$.

W tak ukształtowanym zakresie ograniczenia przenoszenia zabytku ruchomego, z punktu widzenia ochrony jego i jego otoczenia, można dostrzec kilka luk. Warto zwrócić uwagę, że nadzorem konserwatorskim objęto tylko przeniesienie samego zabytku, podczas gdy zasadniczo uzyskiwanie pozwoleń jest niekonieczne na dokonywanie zmian we wnętrzu wobec elementów niebędących zabytkami ruchomymi, nawet jeśli negatywnie może wpływać to na ekspozycję zabytku. Zastanawia także, dlaczego punktem odniesienia ma być wyłącznie tradycja w wystroju danego wnętrza, która zresztą - jak zauważa się w doktrynie - wobec spowodowanej wydarzeniami historycznymi XX w. destrukcji wielu zabytków często bywa dziś iluzoryczna ${ }^{17}$. Tradycyjne umiejscowienie zabytku może zatem odzwierciedlić jego wartość historyczną, podczas gdy niekoniecznie wyczerpuje problem jego właściwej ekspozycji pod względem wartości artystycznej czy naukowej ${ }^{18}$.

16 P. Antoniak, M. Cherka, F.M. Elżanowski, K.A. Wąsowski, Ustawa o ochronie zabytków i opiece nad zabytkami. Komentarz, Wolters Kluwer, Warszawa 2010, LEX.

17 Ibidem.

18 Szukając analogii z porządkami prawnymi innych państw, warto zwrócić uwagę na obowiązującą we francuskim Kodeksie dziedzictwa (Code du patrimoine, version consolidée au 1 janvier 2020, https:// www.legifrance.gouv.fr/affichCode.do?cidTexte=LEGITEXT000006074236 [dostęp: 30.01.2020]) instytucję servitude de maintien dans les lieux (dosłownie: służebność utrzymania w danym miejscu). Obciążone taką służebnością na podstawie art. L622-1 wspomnianego aktu prawnego są zabytki ruchome stanowiące spójną całość z zabytkami nieruchomymi, z którymi połączone są szczególnymi więzami historycznymi lub artystycznymi i których zachowanie $w$ danym miejscu jest zgodne $z$ interesem publicznym. Jak zaznaczają komentatorzy francuskich regulacji, w praktyce oznacza to m.in. objęcie nadzorem przemieszczania zabytków ruchomych, także w obrębie zabytku nieruchomego (zob. F. Monamy, Droit du patrimoine servitude 


\section{ARTYKUEY}

Agata Lizak

Porównując zaś postanowienia ustawy o ochronie zabytków i opiece nad zabytkami z relewantnymi przepisami ustawy o ochronie dóbr kultury, zauważyć da się, że obecnie zawężono zakres ograniczenia przenoszenia zabytku ruchomego na dwóch polach. W art. 27 ust. 2 u.o.d.k., lege non distinguente, nawet krótkotrwałe przeniesienie zabytku ruchomego wymagało zezwolenia kompetentnego organu. Obecną zmianę, ograniczającą konieczność ubiegania się o pozwolenie do przemieszczeń trwałych, należy ocenić w tym kontekście jako zasadną z praktycznego punktu widzenia (poprzednie postanowienia, interpretowane dosłownie, mogły prowadzić do nadmiernego obciążenia wojewódzkiego konserwatora zabytków koniecznością rozstrzygania o kwestiach niemających kluczowego znaczenia dla ochrony danego zabytku, a ponadto nie uwzględniały zasady pomocniczości i proporcjonalności). Dalej, w świetle ustawy o ochronie dóbr kultury pod nadzorem władz konserwatorskich pozostawało nie tylko przeniesienie naruszające ustalone tradycją wnętrze (jak ma to miejsce w przepisach ustawy o ochronie zabytków i opiece nad zabytkami), ale też jego kompozycję, w czym można dostrzec intencję zachowania wartości także artystycznych - tego zaś w obecnej ustawie moim zdaniem niezasadnie zabrakło. Znów zastanawiać można się natomiast, czy kwestia przenoszenia zabytku ruchomego $\mathrm{w}$ obrębie zabytku nieruchomego powinna być przedmiotem zainteresowania władz konserwatorskich w przypadku zbiorów prywatnych - ani w przepisach ustawy o ochronie dóbr kultury, ani ustawy o ochronie zabytków i opiece nad zabytkami rozróżnienia takiego nie ma.

\section{Właściwe wyeksponowanie zabytków 0 „problematycznej ruchomości”}

Problem właściwego wyeksponowania zabytków ruchomych widoczny jest szczególnie w odniesieniu do obiektów, których - jak stwierdzono w tekście opublikowanym na stronie Narodowego Instytutu Dziedzictwa - „ruchomość” jest problematyczna ${ }^{19}$. Mowa tu w szczególności o:

- wpisanych indywidualnie do rejestru zabytków ruchomych detalach i dekoracjach architektonicznych (np. polichromiach),

- stale połączonych z podłożem elementach wyposażenia wnętrz (np. kominkach, piecach),

- obiektach małej architektury (np. kapliczkach, przydrożnych krzyżach, rzeźbach ogrodowych).

de maintien dans les lieux des objets mobiliers une avancée salutaire et de sérieuses limites, "Chronique Juridique” 2017, nr 272, s. 97-98). Mechanizm ten wydaje się być ciekawy i wart rozważenia de lege ferenda, gdyż łączy on kwestie uregulowane w art. 36 ust. 1 pkt 7 u.o.z. z problematyką integralności zabytków ruchomych i nieruchomych.

19 Zob. https://www.nid.pl/pl/Dla_specjalistow/Badania_i_dokumentacja/zabytki-ruchome/ [dostęp: 4.04.2020]. 
Z punktu widzenia prawa cywilnego, na gruncie którego definiuje się pojęcie „nieruchomość”, wyżej wymienione obiekty nierzadko stanowią część składową nieruchomości lub jej przynależność ${ }^{20}$. Tym samym, nawet jeśli na gruncie ustawy o ochronie zabytków i opiece nad zabytkami pojęcie nieruchomości i ruchomości wykazuje swoją specyfikę i nie powinno być wprost utożsamiane z cywilistycznym znaczeniem ${ }^{21}$, trudno zupełnie nie posiłkować się definicjami z ustawy z dnia 23 kwietnia 1964 r. - Kodeks cywilny 22 (dalej: k.c.). W tym miejscu wskazać należy, że zgodnie $z$ art. 47 § 2 k.c., częściami składowymi nieruchomości jest wszystko, co nie może być od niej odłączone bez uszkodzenia lub istotnej zmiany całości albo bez uszkodzenia lub istotnej zmiany przedmiotu odłączonego. Jak doprecyzowano w art. 48 k.c., do części składowych gruntu należą w szczególności budynki i inne urządzenia trwale z gruntem związane, a także drzewa i inne rośliny od chwili zasadzenia lub zasiania. Stosownie zaś do art. 51 § 1 k.c., przynależnościami są rzeczy ruchome potrzebne do korzystania z innej rzeczy (rzeczy głównej) zgodnie z jej przeznaczeniem, jeżeli pozostają z nią w faktycznym związku odpowiadającym temu celowi.

Według powyższej klasyfikacji, pierwsza grupa zabytków o „problematycznej ruchomości", tj. detale i dekoracje architektoniczne, w istocie stanowi części składowe nieruchomości ${ }^{23}$. W konsekwencji powinny one być chronione na równi z nieruchomością, w której się znajdują; uwaga ta dotyczy również ich otoczenia. Problemem może być jednak sytuacja, w której jedynie detal lub dekoracja zostały uznane za zabytek i wpisane do rejestru, a nieruchomość, której obiekty te stanowią element, indywidualnie statusu takiego nie ma. Wówczas $w$ istocie trudno znaleźć jakikolwiek przepis ustawy o ochronie zabytków i opiece nad zabytkami, który wobec błędnego zakwalifikowania wyżej wymienionych obiektów do zabytków ruchomych chroniłby ich wyeksponowanie. W szczególności przepisami takimi nie będą regulacje, o których mowa w pkt 3 niniejszego tekstu (odnoszące się do ograniczeń w przenoszeniu zabytku ruchomego), gdyż omawiane obiekty, stanowiąc część rzeczy nieruchomych, przenoszeniu nie podlegają. Utrudnione byłoby stosowanie analogii legis z przepisów dotyczących otoczenia zabytku nieruchomego, gdyż otoczenie to - by korzystać z pełnej ochrony - musi być również wpisane do rejestru, a systemowa wykładnia art. 9 ust. 2 u.o.z. wskazuje, że wpis ten może objąć wyłącznie otoczenie zabytku nieruchomego (jedynie o zabytkach nieruchomych traktuje bowiem art. 9 u.o.z.).

20 M. Drela, Zabytkowe części składowe i przynależności a przedmiot wpisu do rejestru zabytków - uwagi de lege lata i de lege ferenda, „Roczniki Nauk Prawnych” 2017, nr 27/3, s. 32-33.

21 Zob. np. K. Zalasińska, Prawna ochrona zabytków nieruchomych w Polsce, Wolters Kluwer Polska, Warszawa 2010, s. 131 i n.; A. Ginter, A. Michalak, Ustawa o ochronie zabytków i opiece nad zabytkami. Komentarz, Wolters Kluwer Polska, Warszawa 2016, LEX; uchwała Naczelnego Sądu Administracyjnego z dnia 19 października 2015 r., sygn. II OPS 3/15.

22 Ustawa z dnia 23 kwietnia 1964 r. - Kodeks cywilny, tekst jedn. Dz.U. z 2019 r., poz. 1145 ze zm.

23 M. Drela, op. cit., s. 32. 


\section{ARTYKUEY}

Agata Lizak

Co do drugiej z wyżej wymienionych kategorii zabytków, tj. stale połączonych z podłożem elementów wyposażenia wnętrz, w zakresie wyeksponowania obiekty te mogą korzystać jedynie z pośrednich, szczątkowych mechanizmów ochronnych, opisanych we wcześniejszych fragmentach tekstu. Tym samym na ich ekspozycję w ograniczony sposób może wpływać ochrona samej nieruchomości, w której się znajdują (np. poprzez objęcie nadzorem konserwatorskim prac w jej wnętrzu, jeśli nieruchomość sama jest zabytkiem wpisanym do rejestru); ponadto ich przeniesienie, w sytuacji gdy będzie trwałe i prowadzące do naruszenia ustalonego tradycją wystroju wnętrza, wymagać będzie pozwolenia konserwatorskiego (art. 36 ust. 1 pkt 7 u.o.z.).

Wątpliwości zachodzą również w przypadku wpisu do rejestru zabytków ruchomych elementów tzw. małej architektury, które od typowych zabytków ruchomych odróżnia to, że nie znajdują się wewnątrz żadnego obiektu budowlanego. W rezultacie de lege lata kwestia ich umiejscowienia (a zatem i wyeksponowania) nie jest w żaden sposób objęta nadzorem konserwatorskim - w szczególności obiektów małej architektury nie dotyczy art. 36 ust. 7 pkt 1 u.o.z. (gdyż ze względu na zewnętrzne usytuowanie nie może dojść do naruszenia wystroju wnętrza) ani art. 9 ust. 2 u.o.z., który choć odnosi się do ochrony otoczenia zabytku, jak już wspomniano, może być stosowany wyłącznie wobec nieruchomości.

Problemy te wydają się potwierdzać, że przyjęty w ustawie o ochronie zabytków i opiece nad zabytkami dualistyczny, odbiegający od dotychczasowego podejścia (prezentowanego w ustawie o ochronie dóbr kultury) model podejścia do ochrony zabytków, z wyraźnym podziałem na zabytki nieruchome i ruchome, wpraktyce nie spełnia swojej roli. Nawet jeśli w tym przypadku głównym problemem jest błędna wykładnia przepisów ustawy o ochronie zabytków i opiece nad zabytkami, źle świadczy to o ich jakości pod względem jasności i poprawności legislacyjnej.

\section{Właściwe wyeksponowanie zabytków ruchomych w kontekście ogólnych obowiązków dysponenta zabytku}

Kolejnym przedmiotem refleksji warto uczynić to, czy obowiązków związanych z właściwym wyeksponowaniem zabytku ruchomego nie da się wyinterpretować ze skierowanych do właściciela/posiadacza zabytku ogólnych zasad opieki nad zabytkami, określonych $\mathrm{w}$ art. 5 u.o.z. W tym kontekście na uwagę zasługuje m.in. art. 5 pkt 3 u.o.z., zgodnie z którym właściciel lub posiadacz zabytku powinien zapewnić warunki zabezpieczenia i utrzymania zabytku oraz jego otoczenia w jak najlepszym stanie. Zastanawiać może, czy pojęcie „otoczenie” użyte w tym miejscu przez ustawodawcę należy interpretować zgodnie z definicją z art. 3 pkt 15 u.o.z. Za takim podejściem przemawiać mogą reguły wykładni językowej, zgodnie z którymi poszczególnym zwrotom trzeba przypisywać znaczenie, jakie prawodawca nadał im za pomocą definicji legalnej. Niemniej art. 5 pkt 3 u.o.z. dotyczy zabez- 
pieczenia i utrzymania każdego rodzaju zabytku²4, a poprzez użycie zaimka „jego” ustawodawca w tym przypadku ściśle łączy pojęcie otoczenia z będącym przedmiotem wyżej wymienionego zabezpieczenia i utrzymania zabytkiem. W konsekwencji istnieją pewne podstawy do uznania, że intencją ustawodawcy było nadanie pojęciu „otoczenie” szerszego znaczenia, aniżeli wskazuje na to definicja legalna. Taka interpretacja znajdowałaby również uzasadnienie funkcjonalne, gdyż otoczenie rozumiane zgodnie $z$ art. 3 pkt 15 u.o.z. (tj. jako przedmiot odrębnego wpisu do rejestru) zyskuje na znaczeniu raczej z punktu widzenia możliwych do podjęcia środków nadzoru konserwatorskiego, a nie sposobu sprawowania opieki nad zabytkiem przez samego dysponenta (której zakres może być szerszy aniżeli zakres możliwej ingerencji ze strony władz administracyjnych).

Pewnych uwarunkowań właściwego wyeksponowania zabytków ruchomych można dopatrywać się również w uregulowaniach art. 5 pkt 4 u.o.z., zgodnie z którym opieka nad zabytkami polega także na zapewnieniu warunków korzystania z zabytku w sposób zapewniający trwałe zachowanie jego wartości. Jak już sygnalizowano w poprzednich częściach niniejszego tekstu, wartość zabytku ruchomego (historyczna, artystyczna, naukowa) w pewnej mierze może zależeć również od jego powiązań z elementami otoczenia. W tym zakresie przytoczoną regulację można zatem interpretować jako mieszczącą w sobie zakaz korzystania z zabytku ruchomego w sposób negatywnie wpływający na jego wartość wynikającą z właściwego wyeksponowania ${ }^{25}$.

Omawiając obowiązki dysponentów zabytków, w kontekście rozwiązań historycznych warto wspomnieć o charakterystycznym rozwiązaniu przyjętym w art. 25 ust. 2 u.o.d.k., który przewidywał obowiązek użyczenia zabytku ruchomego przez jego właściciela, na podstawie decyzji wojewódzkiego konserwatora zabytków, dla celów wystawienniczych na okres nie dłuższy od sześciu miesięcy w ciągu każdych pięciu lat. W ten sposób najsilniej ingerowano w kwestię eksponowania zabytków ruchomych, całkowicie pozbawiając właściciela decyzyjności w tym zakresie. Postanowienie to budziło liczne kontrowersje, gdyż prowadziło do czasowego pozbawienia posiadania zbiorów, $w$ tym także tych prywatnych. Jak wskazuje się w doktrynie, celem regulacji była nie tyle ochrona zabytku, ile jego upowszechnienie wśród społeczeństwa ${ }^{26}$. W tym zakresie wydaje się, że słusznie

\footnotetext{
24 Lege non distinguente - nieruchomego i ruchomego, wpisanego, ale też niewpisanego do rejestru.

25 Warto na marginesie zauważyć, że brak realizacji obowiązków z art. 5 u.o.z. w odniesieniu do zabytków ruchomych rodzi znacznie mniejsze sankcje dla właściciela/posiadacza, aniżeli może mieć to miejsce w przypadku zabytkowych nieruchomości. Przykładowo, dla właścicieli zabytków nieruchomych wpisanych indywidualnie do rejestru brak wypełniania obowiązków z art. 5 u.o.z. może skutkować brakiem uprawnienia do skorzystania z ulg podatkowych. Tego typu sankcja nie występuje w przypadku ruchomości.

26 A. Jagielska-Burduk, op. cit., s. 135. Na fakt, że w ustawie o ochronie dóbr kultury kładziono silny nacisk na udostępnianie dziedzictwa społeczeństwu, zwracano uwagę we wcześniejszych opracowaniach (zob. np. K. Malinowski, Co wnosi nowego ustawa o ochronie dóbr kultury i o muzeach?, „Ochrona Zabytków” 1962, nr 15/2(57), s. 5).
} 


\section{ARTYKUEY}

Agata Lizak

do ustawy o ochronie zabytków i opiece nad zabytkami nie wprowadzono odpowiednika tej regulacji jako zbyt restrykcyjnej. Można przypuszczać, że cel upowszechniania zabytku wśród społeczeństwa dałoby się osiągnąć innymi metodami (np. poprzez zachęty finansowe do jego eksponowania) ${ }^{27}$.

\section{Podsumowanie}

Analiza problemu uregulowania zasad właściwego eksponowania zabytków ruchomych pozwala dostrzec kilka wad systemu prawnej ochrony zabytków. Na przykładzie omawianego zagadnienia widać, że sztywny podział zabytków na ruchome i nieruchome nie zawsze służy ich pełnej ochronie, nie pozwalając na uwzględnienie wzajemnych powiązań między dwoma kategoriami. Konsekwencją wspomnianego dualizmu, przynoszącą negatywne skutki również na polu omawianego problemu, jest też występujące w praktyce "mieszanie" obu kategorii, polegające na objęciu nieruchomości (lub ich części) ochroną właściwą zabytkom ruchomych. Za niefortunną należy uznać także redakcję przepisu wprowadzającego ograniczenie w przenoszeniu zabytku ruchomego z naruszeniem ustalonego tradycją wystroju wnętrza - przepis ten pozwala jedynie na bardzo wybiórczą ochronę otoczenia zabytku ruchomego. $Z$ kolei art. 5 u.o.z., jako przepis ogólny i również nieodnoszący się bezpośrednio do problemów wyeksponowania zabytków ruchomych, także nie może być uznany za wystarczający.

Uwagi te prowadzą do wniosku, że zasadne byłoby wprowadzenie zmian w przepisach. W pewnym stopniu problemy z właściwym wyeksponowaniem zabytków ruchomych mogłyby zostać wyeliminowane poprzez rezygnację z rozłącznego traktowania zabytków ruchomych i nieruchomych oraz powrót do wzorca z ustawy o ochronie dóbr kultury. Pozwoliłoby to na ujednolicenie środków nadzoru konserwatorskiego oraz traktowanie nieruchomości i jej wyposażenia jako jednej całości, prezentującej spójną wartość zabytkową.

Ponadto $w$ odniesieniu do ruchomości podlegających ochronie indywidualnie (bez jednoczesnego objęcia ochroną nieruchomości, w której się znajdują) warto rozważyć zmianę redakcji i uproszczenie art. 36 ust. 1 pkt 7 u.o.z., tak by pozwolenia wojewódzkiego konserwatora zabytków wymagało każde trwałe przeniesienie zabytku ruchomego. Człon aktualnie obowiązującego art. 36 ust. 1 pkt 7 u.o.z., zgodnie z którym przeniesienie to miałoby powodować naruszenie ustalonego tradycją wystroju wnętrza, należy uznać za zbędny - jak już wspomniano, to nie wnętrze samo w sobie ma być tu bowiem przedmiotem ochrony, lecz zabytek ruchomy. Co więcej, brak dodatkowych przesłanek dla stosowania ograniczenia w przeno-

27 W tym kontekście warto wspomnieć m.in. o modelu przyjętym w Czarnogórze - w art. 112 ustawy z dnia 27 lipca 2010 r. o ochronie dziedzictwa kulturowego (Protection of cultural property act of 27 July 2010, https://en.unesco.org/cultnatlaws [dostęp: 2.04.2020]) wprowadzono rozwiązanie, zgodnie z którym właściciel zabytku ruchomego ma prawo wystawiać go w przestrzeniach wystawienniczych instytucji publicznych bez ponoszenia kosztów za użytkowanie tej przestrzeni lub organizację wystawy. 
szeniu zabytku ruchomego byłby analogiczny do zakresu art. 36 ust. 1 pkt 6 u.o.z., odnoszącego się do przemieszczania zabytku nieruchomego. Wprowadzić można by nowe ograniczenie, dotyczące konieczności uzyskania pozwolenia na dokonywanie trwałych zmian we wnętrzu, w którym znajduje się zabytek ruchomy, które to zmiany wywierają negatywny wpływ na jego ekspozycję lub na jego wartość historyczną, artystyczną lub naukową.

Wydaje się jednak, że w omawianym zakresie poprzestać należy na udoskonaleniu wspomnianych mechanizmów pośrednich, bez wprowadzania do przepisów bezwzględnego obowiązku udostępniania zabytków ruchomych publiczności, a tym samym - także bez wprowadzania przepisu wprost przewidującego obowiązek właściwego eksponowania. Rozwiązania takie mogłyby być bowiem postrzegane jako nieproporcjonalne ograniczenie prawa własności zabytku - choć samo eksponowanie może być rozumiane szerzej niż tylko udostępnienie zabytku ruchomego publiczności ${ }^{28}$, ingerowanie w nie za pomocą środków nadzoru lub sankcji byłoby zbyt daleko idące, w szczególności w przypadku zbiorów prywatnych, przy braku prawnego obowiązku udostępniania zabytku publiczności. Ponadto wątpliwości powstałyby co do skuteczności tego typu regulacji - można przypuszczać, że właściwsze w tym zakresie byłoby prowadzenie odpowiednich działań edukacyjnych lub wprowadzenie swoistego systemu preferencji dla osób chcących właściwie eksponować zabytki (np. poprzez umożliwienie dofinansowania prac w tym zakresie, także w odniesieniu do wnętrz, w których znajdują się zabytki ruchome $)^{29}$. Z tego też względu de lege ferenda można by rozważyć zróżnicowanie obowiązków dysponentów zabytków ruchomych, przykładowo rozciągając ochronę wyposażenia zabytku nieruchomego lub restrykcje w zakresie przenoszenia zabytku ruchomego w obrębie obiektu, w którym już się on znajduje tylko na przypadki zabytków faktycznie udostępnianych publiczności.

\section{Bibliografia}

Act of 9 June 1978, No. 50, Concerning the Cultural Heritage, https://www.regjeringen.no/ en/dokumenter/cultural-heritage-act/id173106/ [dostęp: 3.04.2020].

Antoniak P., Cherka M., Elżanowski F.M., Wąsowski K.A., Ustawa o ochronie zabytków i opiece nad zabytkami. Komentarz, Wolters Kluwer, Warszawa 2010, LEX.

Code du patrimoine, version consolidée au 1 janvier 2020, https://www.legifrance.gouv.fr/ affichCode.do?cidTexte=LEGITEXT000006074236 [dostęp: 30.01.2020].

Drela M., Zabytkowe części składowe i przynależności a przedmiot wpisu do rejestru zabytków uwagi de lege lata i de lege ferenda, „Roczniki Nauk Prawnych” 2017, nr 27/3.

Dunaj B. (red.), Słownik współczesnego języka polskiego, t. 1-2, Wydawnictwo Wilga, Warszawa 1998.

\footnotetext{
28 To jest, jak wspomniano we wprowadzeniu, po prostu jako właściwe, podkreślające walory zabytku umieszczenie na tle innych obiektów, bez względu na fakt publicznego udostępnienia.

29 Byłoby to działanie za pomocą „nagród w prawie”, motywujących do podejmowania określonych działań (zob. K. Zeidler, Prawo ochrony dziedzictwa kultury, Gdańsk 2007, LEX).
} 


\section{ARTYKUtY}

Agata Lizak

Explanatory report on the Convention for the Protection of the Architectural Heritage of Europe, https://rm.coe.int/CoERMPublicCommonSearchServices/DisplayDCTMContent?documentld=09000016800ca436 [dostęp: 2.04.2020].

Ginter A., Michalak A., Ustawa o ochronie zabytków i opiece nad zabytkami. Komentarz, Wolters Kluwer Polska, Warszawa 2016, LEX.

https://www.nid.pl/pl/Dla_specjalistow/Badania_i_dokumentacja/zabytki-ruchome/ [dostęp: 4.04.2020].

https://www.nid.pl/pl/Informacje_ogolne/Zabytki_w_Polsce/rejestr-zabytkow/zestawienia-zabytkow-ruchomych/ [dostęp: 3.04.2020]).

Jagielska-Burduk A., Zabytek ruchomy, Wolters Kluwer Polska, Warszawa 2011.

Konwencja o ochronie dziedzictwa architektonicznego Europy z dnia 3 października 1985 r., Dz. U. z 2012 r., poz. 210.

Malinowski K., Co wnosi nowego ustawa o ochronie dóbr kultury i o muzeach?, „Ochrona Zabytków" 1962, nr 15/2(57).

Monamy F., Droit du patrimoine servitude de maintien dans les lieux des objets mobiliers une avancée salutaire et de sérieuses limites, „Chronique Juridique” 2017, nr 272.

Protection of cultural property act of 27 July 2010, https://en.unesco.org/cultnatlaws [dostęp: 2.04.2020].

Pruszyński J., Regulacja ustawowa ochrony zabytków, „Ochrona Zabytków” 1985, nr 38/1(148).

Pruszyński J., Stan i potrzeby regulacji prawnej ochrony zabytków w Polsce, „Ochrona Zabytków" 1996, nr 49/3(194).

Rozporządzenie Ministra Kultury i Dziedzictwa Narodowego z dnia 22 czerwca 2017 r. w sprawie prowadzenia prac konserwatorskich, prac restauratorskich i badań konserwatorskich przy zabytku wpisanym do rejestru zabytków albo na Listę Skarbów Dziedzictwa oraz robót budowlanych, badań architektonicznych i innych działań przy zabytku wpisanym do rejestru zabytków, a także badań archeologicznych i poszukiwań zabytków, Dz. U. poz. 1265.

Sieroszewski W., Czy ustawa o ochronie dóbr kultury i o muzeach dojrzała do nowelizacji: artykuł dyskusyjny, „Ochrona Zabytków” 1971, nr 24/3(94).

Uchwała Naczelnego Sądu Administracyjnego z dnia 19 października 2015 r., sygn. II OPS $3 / 15$.

Ustawa z dnia 15 lutego 1962 r. o ochronie dóbr kultury, tekst jedn. Dz. U. z 1999 r. Nr 98, poz. 1150 ze zm.

Ustawa z dnia 23 kwietnia 1964 r. - Kodeks cywilny, tekst jedn. Dz.U. z 2019 r., poz. 1145 ze zm.

Ustawa z dnia 21 listopada 1996 r. o muzeach, tekst jedn. Dz.U. z 2019 r., poz. 917 ze zm.

Ustawa z dnia 23 lipca 2003 r. o ochronie zabytków i opiece nad zabytkami, tekst jedn. Dz. U. z 2018 r., poz. 2067 ze zm.

Zalasińska K., Prawna ochrona zabytków nieruchomych w Polsce, Wolters Kluwer Polska, Warszawa 2010.

Zeidler K., Nowe zobowiązania międzynarodowe Polski w zakresie ochrony dziedzictwa kultury, „Gdańskie Studia Prawnicze” 2013, t. 29.

Zeidler K., Prawo ochrony dziedzictwa kultury, Gdańsk 2007, LEX. 